\title{
Peningkatan Kualitas Sabut Kelapa Melalui Teknologi Fermentasi Menggunakan Mikroba Pencerna Serat Terseleksi dari Cairan Rumen Kerbau
}

\author{
S. Aminah ${ }^{1 *}$, L. K. Nuswantara' , B. I. M. Tampoebolon², S. Sunarso² \\ ${ }^{1}$ Program Studi Magister Ilmu Ternak, Universitas Diponegoro, Semarang, Indonesia 50275 \\ ${ }^{2}$ Fakultas Peternakan dan Pertanian, Universitas Diponegoro, Semarang, Indonesia 50275
}

\begin{abstract}
ABSTRAK
Penelitian ini bertujuan untuk mendapatkan kultur mikroba pencerna serat terbaik dari cairan rumen kerbau dan mengkaji pengaruh perbedaan lama pemeraman dan persentase penggunaan starter mikroba pencerna serat terseleksi terhadap komponen proksimat sabut kelapa fermentasi. Penelitian ini terdiri dari dua tahap. Tahap I adalah seleksi mikroba pencerna serat dari cairan rumen kerbau menggunakan substrat yang berbeda. Percobaan menggunakan Rancangan Acak Lengkap (RAL) dengan 5 perlakuan dan 5 ulangan. Peubah yang diamati adalah aktivitas dan aktivitas spesifik enzim endoglukanase, eksoglukanase dan xilanase. Tahap II adalah perlakuan fermentasi sabut kelapa menggunakan kultur terseleksi dengan perbedaan persentase penggunaan inokulum ( $0,2,5$ dan 5\%) dan lama peram (0, 7 dan 14 hari). Percobaan menggunakan RAL faktorial 3x3 dan 4 ulangan. Peubah yang diamati adalah komponen proksimat. Data dianalisis menggunakan analisis ragam, dilanjutkan Uji Jarak Berganda Duncan. Hasil penelitian tahap I menunjukkan aktivitas spesifik enzim endoglukanase, eksoglukanase dan xilanase tertinggi $(\mathrm{P}<0,05)$ pada penggunaan substrat kulit kacang, berturut-turut sebesar 0,$020 ; 0,022$; 0,018 unit $/ \mathrm{ml} / \mathrm{menit}$. Hasil penelitian tahap II menunjukkan kadar serat kasar $(\mathrm{SK})$ terendah $(\mathrm{P}<0,05)$ terjadi pada kombinasi perlakuan $\mathrm{P}_{1} \mathrm{H}_{2}, \mathrm{P}_{2} \mathrm{H}_{1}$ dan $\mathrm{P}_{2} \mathrm{H}_{2}$, berturut-turut sebesar 51,70; 49;90; 49,91\%. Kadar lemak kasar (LK) dan abu tertinggi $(\mathrm{P}<0,05)$ secara berturut-turut terjadi pada kombinasi perlakuan $\mathrm{P}_{2} \mathrm{H}_{2}$ sebesar 16,03\% dan $\mathrm{P}_{1} \mathrm{H}_{2}$ sebesar 16,99\%. Kesimpulan penelitian ini adalah penggunaan substrat kulit kacang menghasilkan kultur mikroba pencerna serat terbaik dan meningkatkan kualitas sabut kelapa. Peningkatan kualitas terjadi seiring dengan peningkatan penggunaan inokulum dan lama pemeraman. Kualitas sabut kelapa terbaik terjadi pada penggunaan inokulum sebanyak 5\% dan pemeraman selama 14 hari ditinjau dari kadar protein kasar (PK) dan SK.
\end{abstract}

Kata kunci: Cairan rumen kerbau, Sabut kelapa, Fermentasi, komponen proximat, Enzim pencerna serat

\section{Improving The Quality of Coconut Husk Through Fermentation Technology Using Selected Fiber Degrading Microbes from Buffalo Rumen Fluid}

\begin{abstract}
The study aims to obtain the best fiber-degrading microbial culture from buffalo rumen fluid and examine the effect of differences fermented period and percentage of selected fiber-degreding microbes starter on fermented coconut husk proximate component. This research was conducted into two experiments. First experiment was fiber-degrading microbes selection from buffalo rumen fluid using different substrates. Completely randomized design with 5 treatments and 5 replications was used in this experiment. Variables observed were endoglucanases, exoglucanases and xylanases enzymes activity and spesific activities. Second experiments was treatment of coconut husk fermentation used selected cultures with different treatments of inoculum level (0, 2.5 and 5\%) and fermentation period (0, 7 and 14 days). Completely randomized factorial design $3 \times 3$ with 5 replications was used in this experiment. Variables observed were proximate component. Analysis of variance was used and continued by Duncan's Multiple Range Test. First experiment results showed nutshells substrate the highest $(P<0.05)$ endoglucanases, exoglucanases and xylanases enzyme specific activities, respectively 0.020; 0.022; 0.018units/ml/minute. Second experiment results showed that the lowest $(P<0.05)$ level of crude fiber was occurs at treatments combination $P_{1} H_{2}$, $P_{2} \mathrm{H}_{1}$ and $\mathrm{P}_{2} \mathrm{H}_{2}$, respectively 51.70; 49.90; 49.91\%. The highest $(P<0.05)$ level of crude lipid and ash value respectively was occurs at treatments combination $\mathrm{P}_{2} \mathrm{H}_{2}$ of $16.03 \%$ and $\mathrm{P}_{1} \mathrm{H}_{2}$ of $16.99 \%$. Nutshells substrate produces the best fiber-degrading microbial culture and coconut husk quality. The best quality was occurs at $5 \%$ of inoculum and 14 days of fermented period in terms of crude protein and crude fiber.
\end{abstract}

Keywords: Buffalo rumen fluid, Coconut husk, Fermentation, Proximate component, Fiber-degrading enzymes

\section{PENDAHULUAN}

Ketersediaan pakan lokal berkesinambungan menentukan keberlanjutan usaha peternakan. Namun, ketersediaan hijauan pada saat ini menjadi terbatas dikarenakan pengaruh musim atau pergeseran fungsi lahan pertanian menjadi non-pertanian. Ketersediaan pakan yang mencukupi secara kualitas dan kuantitas, dapat meningkatkan produktivitas ternak (Sitindaon,

*Penulis Korespondensi: Siti Aminah

Alamat: Desa Padomasan, Reban, Batang, Jawa Tengah, 51273

E-mail: sitiaminah23@gmail.com
2013). Berdasarkan hal tersebut perlu dilakukan upaya untuk menggunakan dan meningkatkan kualitas nutrien dari pakan alternatif yang ketersediaannya melimpah. Tahun 2018 Indonesia menghasilkan kelapa sebanyak 2,9 juta ton (BPS, 2018) dengan proporsi sabutnya sebanyak 35\% dalam satu butir kelapa (Haryanto dan Suheryanto, 2014), berdasarkan hal tersebut diperkirakan sabut kelapa yang dihasilkan sebanyak 1,01 juta ton. Sabut kelapa mengandung kadar air $5,43 \%$, abu 3,95\%, dan serat kasar 30,34\% (Adeyi, 2010) dan protein kasar 3,13\% (Lorica dan Uyenco, 1982). Sabut kelapa juga kaya kandungan nutrien 
makro yaitu kalium dan fosfor (Neto et al., 2004; Rahmadani, 2011). Hal tersebut menunjukkan bahwa ketersediaan sabut kelapa yang melimpah dapat digunakan sebagai alternatif pakan pengganti hijauan, namun tingginya kandungan serat kasar dan rendahnya kandungan protein kasar menyebabkan rendahnya nilai kecernaan sehingga perlu upaya untuk meningkatkan kualitas nuteriennya.

Sabut kelapa dapat ditingkatan kualitas nutriennya dengan cara pengolahan pakan menggunakan teknologi fermentasi. Fermentasi dapat diterapkan dengan memanfaatkan mikroorganisme dari rumen ternak ruminansia yang dapat menghasilkan enzim pendegradasi serat. Isolasi mikroba pencerna serat dari rumen kerbau didasari atas kemampuannya dalam memanfaatkan pakan menjadi lebih efisien dibandingkan sapi pada kondisi pemeliharaan yang sama (Wanapat et al., 1994). Hal tersebut terkait dengan tingginya jumlah total bakteri dan persentase mikroba selulolitik dari rumen kerbau dibanding sapi (Pradhan, 1994) yaitu sebanyak 3,3 x $10^{9} \mathrm{CFU} / \mathrm{ml}$ (Wanapat et al., 2009a), sedangkan sapi sebanyak 2,7 x $10^{8} \mathrm{CFU} / \mathrm{ml}$ (Wanapat et al., 2009b).

Serat tanaman terdiri dari beberapa bagian, yaitu bagian amorf, kristalin, selobiosa dan xilan. Kandungan selulosa dan hemiselulosa pada tiap-tiap tanaman memiliki jumlah yang berbeda, sehingga diperlukan substrat yang mampu mewakili keragaman jenis selulosa dan hemiselulosa. Sabut kelapa, pucuk tebu, tongkol jagung, kulit kacang dan eceng gondok merupakan bahan yang dapat ditemukan sepanjang tahun, selain itu bahan tersebut memiliki kandungan selulosa dan hemiselulosa yang tinggi. Penggunaan kelima bahan tersebut sebagai substrat pada kultur mikroba pencerna serat dari cairan rumen kerbau belum pernah dilakukan. Berdasarkan hal tersebut, perlu dilakukan kajian tentang pengaruh penggunaan substrat yang berbeda pada inokulum cairan rumen kerbau terhadap aktivitas enzim endoglukanase, eksoglukanase dan xilanase. Hal tersebut untuk menentukan starter fermentasi terbaik sebelum diaplikasikan pada sabut kelapa. Tujuan dari penelitian ini adalah: 1) mendapatkan kultur mikroba pencerna serat terbaik dari cairan rumen kerbau, dan 2) mengkaji pengaruh perbedaan lama pemeraman dan persentase penggunaan starter mikroba terseleksi terhadap komponen proksimat sabut kelapa fermentasi.

Tabel 1. Kandungan serat substrat

\begin{tabular}{|c|c|c|c|}
\hline \multirow{2}{*}{ Substrat } & \multicolumn{3}{|c|}{ Kandungan Serat dalam 100\% BK } \\
\hline & Hemiselulosa & Selulosa & Lignin \\
\hline & \multicolumn{3}{|c|}{ |----------------(\%)--------------- } \\
\hline Sabut Kelapa & 8,49 & 15,90 & 14,28 \\
\hline Pucuk Tebu & 17,04 & 20,65 & 10,50 \\
\hline Tongkol Jagung & 33,29 & 30,57 & 15,80 \\
\hline Kulit Kacang & 9,01 & 40,88 & 28,02 \\
\hline Eceng gondok & 27,12 & 22,99 & 8,51 \\
\hline
\end{tabular}

Hasil analisis penelitian di Laboratorium Ilmu Nutrisi dan Pakan Fakultas Peternakan dan Pertanian Universitas Diponegoro Semarang 2019

\section{MATERI DAN METODE}

\section{Waktu dan Lokasi Penelitian}

Penelitian ini dilakukan pada bulan April September 2019 di laboratorium Ilmu Nutrisi dan Pakan, Fakultas Peternakan dan Pertanian Universitas Diponegoro, Semarang. Penelitian ini terdiri dari dua tahap. Tahap I adalah seleksi mikroba pencerna serat. Tahap II adalah aplikasi fermentasi sabut kelapa dengan menggunakan kultur terpilih dari hasil penelitian tahap I.

\section{Penelitian Tahap I}

Bahan yang digunakan adalah cairan rumen kerbau, avicel PH 101 dan glukosa. Cairan rumen kerbau diambil dari Rumah Potong Hewan (RPH) Desa Prambatan Kidul, Kudus. Substrat yang digunakan yaitu sabut kelapa, pucuk tebu, tongkol jagung, kulit kacang, dan eceng gondok. Kandungan selulosa dan hemiselulosa substrat dapat dilihat pada Tabel 1 . Medium isolasi berupa medium cair yang tersusun dari larutan mineral I, mineral II, yeast ekstrak (Merck, Germany), tripton (Sigma-Aldrich, Amerika), cairan rumen kerbau yang telah disentrifuse, $\mathrm{H}_{2} \mathrm{O}, \mathrm{Na}_{2} \mathrm{CO}_{3}$ $12 \%$, sistein $\mathrm{HCl}$ dan $0,1 \%$ resazurin. Larutan mineral I terdiri dari $0,3 \% \mathrm{~K}_{2} \mathrm{HPO}_{4}$, sedangkan larutan mineral II terdiri dari $0,3 \% \mathrm{~K}_{2} \mathrm{HPO}_{4} ; 0,6 \%\left(\mathrm{NH}_{4}\right)_{2} \mathrm{SO}_{4} ; 0,6 \%$ $\mathrm{NaCl} ; 0,06 \% \mathrm{MgSO}_{4}$ dan $0,06 \% \mathrm{CaCl}_{2} \mathrm{H}_{2} \mathrm{O}$. Alat yang digunakan yaitu waterbath merk Memmert WNB 45, autoklaf merk All American model No. 75x, sentrifus merk Hettich Zentrifugen Universal 320R, erlenmeyer, gas $\mathrm{CO}_{2}, \mathrm{pH}$ meter elektrik dan pipet ukur.

\section{Rancangan Percobaan}

Penelitian ini menggunakan RAL dengan 5 perlakuan dan 5 ulangan. Metode yang digunakan dengan cara mengisolasi mikroba pencerna serat dari cairan rumen kerbau menggunakan medium selektif cair dan dengan menggunakan substrat yang berbeda, yaitu $\mathrm{T}_{1}$ : sabut kelapa, $\mathrm{T}_{2}$ : pucuk tebu, $\mathrm{T}_{3}$ : tongkol jagung, $\mathrm{T}_{4}$ : kulit kacang dan $\mathrm{T}_{5}$ : eceng gondok.

\section{Inkubasi Seleksi Kultur}

Cairan rumen kerbau yang baru diambil dari RPH diinkubasi pada suhu $39^{\circ} \mathrm{C}$ selama 16 jam dengan menambahkan $1 \%$ avicel dan $2 \%$ glukosa. Isolasi dilakukan dengan menggunakan $50 \mathrm{ml}$ medium selektif cair dimasukkan ke dalam tabung erlenmeyer yang telah berisi substrat sesuai perlakuan yang diberikan, kemudian menambahkan $2 \%$ cairan rumen kerbau yang telah diinkubasi dengan dialiri gas $\mathrm{CO}_{2}$. Tabung erlenmeyer ditutup rapat dan diinkubasi pada suhu $39^{\circ} \mathrm{C}$ selama 6 hari (Bachrudin et al., 1998).

Kultur mikroba dipanen dan disentrifus dengan kecepatan 3000 rpm selama 10 menit, kemudian diuji aktivitas enzim endoglukanase, eksoglukanase dan xilanase menggunakan metode dinitro salisilic acid (DNS) (Miller, 1959). Aktivitas enzim spesifik dihitung dengan membagi aktivitas enzim dengan kadar protein terlarut supernatan (Machfoed et al., 
1989). Kadar protein terlarut dihitung dengan menggunakan metode Lowry (Plummer, 1971).

Uji aktivitas enzim endoglukanase dan eksoglukanase dilakukan dengan membuat kurva standar glukosa, yakni membuat larutan glukosa dengan konsentrasi $0 ; 0,2 ; 0,4 ; 0,6 ; 0,8$ dan $1 \mathrm{mg} / \mathrm{ml}$. Pengukuran aktivitas enzim endoglukanase dilakukan dengan menambahkan 0,5 ml larutan CMC $10 \mathrm{mg} / \mathrm{ml}$ pada tabung reaksi, sedangkan pengukuran aktivitas enzim eksoglukanase dilakukan dengan menambahkan $0,5 \mathrm{ml}$ larutan avicel $10 \mathrm{mg} / \mathrm{ml}$ pada tabung reaksi. $1 \mathrm{ml}$ buffer sitrat 0,5 $\mathrm{M}$ dan $0,5 \mathrm{ml}$ supernatan ditambahkan pada tabung reaksi kemudian diinkubasi pada suhu $50^{\circ} \mathrm{C}$ selama 30 menit. Larutan DNS sebanyak $3 \mathrm{ml}$ ditambahkan, kemudian dipanaskan dalam air mendidih selama 5 menit. Aquades ditambahkan sebanyak $20 \mathrm{ml}$, kemudian diukur serapan pada panjang gelombang $\lambda 540 \mathrm{~nm}$ dan dicatat nilai absorbannya. Hasil pengukuran absorbansi supernatan dikoreksikan dengan blanko. Aktivitas endoglukanase dan eksoglukanase (unit/ml/menit) dihitung menggunakan rumus:

mg gula pereduksi $\mathrm{x}$ pengenceran

volume supernatan $\mathrm{x}$ berat molekul glukosa $\mathrm{x}$ waktu inkubasi

Uji aktivitas enzim xilanase diukur dengan membuat kurva standar xilosa, yakni membuat larutan xilosa dengan konsentrasi $0 ; 0,2 ; 0,4 ; 0,6 ; 0,8$ dan 1 $\mathrm{mg} / \mathrm{ml}$. Pengukuran aktivitas enzim xilanase dilakukan dengan menambahkan $0,5 \mathrm{ml}$ larutan xilan $10 \mathrm{mg} / \mathrm{ml}, 1$ $\mathrm{ml}$ buffer sitrat $0,5 \mathrm{M}$ dan $0,5 \mathrm{ml}$ supernatan pada tabung reaksi, kemudian diinkubasi pada suhu $50^{\circ} \mathrm{C}$ selama 30 menit. Larutan DNS sebanyak $3 \mathrm{ml}$ ditambahkan pada larutan tersebut, kemudian dipanaskan dalam air mendidih selama 5 menit. Langkah selanjutnya yaitu menambahkan aquades sebanyak $20 \mathrm{ml}$ pada larutan tersebut kemudian diukur serapan pada panjang gelombang $\lambda 540 \mathrm{~nm}$ dan dicatat nilai absorbannya. Hasil pengukuran absorbansi supernatan dikoreksikan dengan blanko. Aktivitas xilanase (unit/ml/menit) dihitung dengan rumus:

mg gula pereduksi $x$ pengenceran

volume supernatan $\mathrm{x}$ berat molekul xylosa $\mathrm{x}$ waktu inkubasi

Uji kadar protein terlarut dilakukan dengan membuat kurva standar larutan bovine serum albumin
(BSA) dengan konsentrasi 0; 0,1;0,2;03;0,4; dan 0,5 $\mathrm{mg} / \mathrm{ml}$. Pengukuran kadar protein terlarut supernatan dilakukan dengan menambahkan $0,5 \mathrm{ml}$ supernatan, 5 $\mathrm{ml}$ reagen lowry ke dalam tabung rekasi, kemudian digojog dan didiamkan selama 10 menit. Langkah selanjutnaya menambahkan $0,5 \mathrm{ml}$ folin kemudian digojok, didiamkan selama 30 menit pada suhu kamar. Larutan diukur nilai absorbannya menggunakan spektrofotometer pada $\lambda 650 \mathrm{~nm}$. Penentuan aktivitas spesfik enzim (unit/g protein/jam) menggunakan rumus:

Aktivitas enzim

Kadar protein terlarut supernatan

\section{Penelitian Tahap II}

Bahan yang digunakan adalah sabut kelapa, inokulum (dengan penambahan kultur terpilih), aquades, molases dan urea. Alat yang digunakan yaitu toples kedap udara.

\section{Rancangan Percobaan}

Penelitian menggunakan RAL dengan pola faktorial 3 x 3 dan 4 ulangan. Faktor A adalah persentase penggunaan inokulum $(0,2,5$ dan $5 \%(\mathrm{ml}$ inokulum / g BK sabut kelapa)). Faktor B adalah lama waktu pemeraman $(0,7$ dan 14 hari).

\section{Fermentasi Sabut Kelapa}

Kultur hasil biakan penelitian tahap I disimpan di lemari pendingin selama dua minggu, kemudian direinokulasi pada medium cair selama 16 jam untuk digunakan sebagai inokulum pada proses fermentasi. Sabut kelapa dicacah ukuran $1-2 \mathrm{~cm}$, kemudian ditimbang $\pm 1 \mathrm{~kg}$ BK. Fermentasi dilakukan dengan menambahkan $0,1 \%$ urea, $3 \%$ molases, aquades (perhitungan kebutuhan kadar air sebanyak 60\% berdasarkan bahan kering sabut kelapa) dan inokulum sebanyak perlakuan yang diberikan. Sabut kelapa yang telah dicampur rata, dimasukkan ke dalam toples kedap udara dan diperam selama waktu perlakuan pemeraman. Sabut kelapa perlakuan diukur komponen proksimatnya berdasarkan metode menurut Association of Official Analytical Chemist (AOAC) (2005).

Analisis kadar PK dilakukan dengan cara menimbang sampel $\pm 1 \mathrm{~g}, 0,3 \mathrm{~g}$ dan $0,4 \mathrm{~g}$ katalisator selenium reagent mixture (pottasium sulfat + cupri

Tabel 2. Rata-rata nilai aktivitas enzim endogluanase, eksoglukanase dan xilanase

\begin{tabular}{cccc}
\hline \hline \multirow{2}{*}{ Perlakuan } & & Parameter & Xilanase \\
\cline { 2 - 4 } & Endoglukanase & Eksoglukanase & $0,217 \pm 0,05^{\mathrm{d}}$ \\
$\mathrm{T}_{1}$ & $----------------------------(U / m 1 / m e n i t)----------------------$ & $0,823 \pm 0,04^{\mathrm{a}}$ \\
$\mathrm{T}_{2}$ & $0,585 \pm 0,06^{\mathrm{c}}$ & $0,669 \pm 0,04^{\mathrm{c}}$ & $0,725 \pm 0,10^{\mathrm{b}}$ \\
$\mathrm{T}_{3}$ & $0,857 \pm 0,09^{\mathrm{a}}$ & $0,940 \pm 0,05^{\mathrm{a}}$ & $0,625 \pm 0,02^{\mathrm{c}}$ \\
$\mathrm{T}_{4}$ & $0,617 \pm 0,06^{\mathrm{bc}}$ & $0,702 \pm 0,04^{\mathrm{c}}$ & $0,842 \pm 0,07^{\mathrm{a}}$ \\
$\mathrm{T}_{5}$ & $0,687 \pm 0,09^{\mathrm{b}}$ & $0,780 \pm 0,07^{\mathrm{b}}$ & $0,797 \pm 0,04^{\mathrm{b}}$ \\
\hline
\end{tabular}

$\overline{\text { a,b,c }}$ superskrip yang berbeda pada kolom yang sama menunjukkan perbedaan yang nyata $(\mathrm{P}<0,05) . \mathrm{T}_{1}=$ sabut kelapa; $\mathrm{T}_{2}=$ pucuk tebu; $\mathrm{T}_{3}=$ tongkol jagung; $\mathrm{T}_{4}=$ kulit kacang; $\mathrm{T}_{5}=$ eceng gondok 
sulfat) dan $15 \mathrm{ml} \mathrm{H}_{2} \mathrm{SO}_{4}$ pekat didestruksi di dalam lemari asam sampai berwarna hijau jernih. Proses destilasi dilakukan dengan menggunakan larutan penangkap $\mathrm{H}_{3} \mathrm{BO}_{3} \quad 4 \%$ sebanyak $20 \mathrm{ml}$ kemudian ditambahkan 2 tetes indikator campuran MR (methyl red) + BCG (brom condeor green). $70 \mathrm{ml}$ aquadest dan $60 \mathrm{ml} \mathrm{NaOH} 45 \%$ ditamnbahkan. Proses destilasi menggunkan $\mathrm{HCl} 0,1 \mathrm{~N}$ sampai larutan penangkap berubah warna dari ungu menjadi hijau. Kadar PK dihitung menggunakan rumus:

$\underline{\text { (titran sampel - blangko) x } \mathrm{NHCl} \text { x ,014 x 6,25 }}$ Sampel

Analisis kadar SK dilakukan dengan menimbang kertas saring Whatman 41 yang telah dikeringkan di dalam oven. Sampel ditimbang kemudian masukkan ke dalam gelas beaker $250 \mathrm{ml}$. Secara berturut-turut ditambahkan larutan $\mathrm{H}_{2} \mathrm{SO}_{4}$ 0,3 N 50 ml, larutan $\mathrm{NaOH}$ 1,5 N $25 \mathrm{ml}$, masing-masing dimasak sampai mendidih selama 30 menit. Larutan disaring menggunakan kertas saring, endapan dicuci berturut-turut dengan $50 \mathrm{ml}$ aquades panas, $50 \mathrm{ml} \mathrm{H}_{2} \mathrm{SO}_{4} 0,3 \mathrm{~N}, 50 \mathrm{ml}$ aquades panas dan $25 \mathrm{ml} \mathrm{N}$-hexane. Kertas saring dan isinya dimasukkan dalam cawan porselain $(\mathrm{CP})$, dioven pada suhu $110^{\circ} \mathrm{C}$ selama 8 jam, kemudian dipijarkan dalam tanur listrik pada suhu $600^{\circ} \mathrm{C}$ selama 4 jam. Tanur dibiarkan dingin, kemudian ditimbang. Kadar SK dihitung menggunakan rumus:

$$
\frac{\begin{array}{l}
(\mathrm{CP}+\text { sampel setelah oven })-(\mathrm{CP}+\text { sampel } \\
\text { setelah tanur })- \text { kertas saring }
\end{array}}{\text { Sampel }} \times 100 \%
$$

Analisis kadar LK dilakukan dengan cara sampel ditimbang dan dibungkus menggunakan kertas saring, kemudian dioven pada suhu $110^{\circ} \mathrm{C}$ sampai diperoleh berat konstan misal beratnya a g. Sampel dimasukkan ke dalam alat soxhlet. Pelarut dietil eter dimasukkan ke dalam soxhlet selanjutnya pasang alat pendingin balik yang dialiri air pendingin, sirkulasi dilakukan sampai jenuh. Sampel dioven sampai diperoleh berat konstan misal beratnya b g. Kadar LK dihitung menggunakan rumus:

$\frac{(\mathrm{CP}+\text { sampel setelah oven })-\mathrm{CP}}{\text { Sampel x }(\text { bahan kering / 100) }} \times 100 \%$

Analisis kadar abu dilakukan dengan cara menimbang CP dan sampel, kemudian dipijarkan dalam tanur listrik pada suhu $600^{\circ} \mathrm{C}$ selama 4 jam. Tanur dibiarkan dingin kemudian ditimbang. Kadar abu dihitng menggunakan rumus:

$\frac{(\mathrm{CP}+\text { sampel setelah tanur })-\mathrm{CP}}{\text { Sampel }} \times 100 \%$

$\operatorname{BETN}(\%)=100 \%-(\% \mathrm{KA}+\% \mathrm{abu}+\% \mathrm{PK}+\% \mathrm{LK}+\% \mathrm{SK})$

\section{Analisis Data}

Data yang diperoleh dianalisis menggunakan analisis ragam, jika terdapat pengaruh nyata perlakuan dilanjutkan dengan uji jarak berganda Duncan. Analisis data dilakukan dengan menggunakan program SPSS Versi 24.

\section{HASIL DAN PEMBAHASAN}

\section{Aktivitas Enzim Selulase}

Rata - rata nilai aktivitas enzim endoglukanase, eksoglukanase dan xilanase disajikan pada Tabel 2. Analisis ragam menunjukkan bahwa penggunaan substrat yang berbeda berpengaruh nyata terhadap aktivitas enzim endoglukanase dan eksoglukanase $(\mathrm{P}<0,05)$. Hasil tersebut menunjukkan bahwa penggunaan substrat yang berbeda menghasilkan aktivitas enzim yang berbeda pula. Hal tersebut disebabkan karena aktivitas enzim selulase dipengaruhi oleh struktur dari substrat. Khoshnevisan et al. (2011) melaporkan menyatakan struktur substrat dapat mempengaruhi produksi enzim, sehingga dapat menurunkan atau meningkatkan efisiensi aktivitasnya. Yunianti et al. (2015) melaporkan kerapatan dinding sel meningkat sejalan dengan meningkatnya kandungan selulosa dan derajat kristalinitas selulosa.

Hasil uji jarak berganda Duncan bahwa aktivitas enzim endoglukanase dan eksoglukanase tertinggi terjadi pada kultur dengan penggunaan substrat berupa pucuk tebu dengan hasil berturut - turut sebesar 0,857 dan $0,940 \mathrm{U} / \mathrm{ml} / \mathrm{menit}$. Hal tersebut disebabkan karena kandungan ligninnya relatif rendah dibandingkan dengan substrat yang lain, sehingga selulosa lebih mudah dihidrolisis oleh mikroba dan digunakan untuk memproduksi enzim selulase. Hal tersebut sejalan dengan pendapat Lee et al. (2009) bahwa renggangnya ikatan lignin terhadap selulosa akan memudahkan mikroorganisme menghidrolisis substrat, sehingga dapat digunakan untuk pertumbuhan ataupun produksi enzim selulase. Guman et al. (2010) melaporkan mikroorganisme sulit menghidrolisis selulosa disebabkan karena masih dilindungi oleh lignin.

Uji jarak berganda Duncan menunjukkan aktivitas enzim endoglukanase dan eksoglukanase terendah terjadi pada kultur dengan penambahan substrat berupa sabut kelapa dengan hasil berturut turut sebesar 0,585 dan $0,669 \mathrm{U} / \mathrm{ml} / \mathrm{menit}$. Hal tersebut disebabkan oleh kandungan selulosa yang relatif redah dibandingkan dengan substrat lain, sehingga kandungan selulosa yang tersedia belum mampu mengoptimalkan produksi enzim selulase. Hal tersebut sejalan dengan pendapat Russel et al. (2009) bahwa penurunan pertumbuhan spesifik enzim disebabkan karena tingkat penambahan substratyang lebih rendah, tetapi penurunan jumlah sel yang diproduksi per unit substratmenunjukkan jalan lain pemanfaatan sumber energi, sehingga bakteri akan tumbuh lebih cepat jika kebutuhan hidup pokoknya terpenuhi. Berdasarkan hal 
tersebut, diketahui bahwa ketersediaan jumlah substrat pada medium berpengaruh terhadap produksi dan aktivitas enzim.

Enzim endoglukanase dan eksoglukanase merupakan enzim pendegradasi selulosa. Singhania et al. (2013) melaporkan enzim endoglukanase menghidrolisis secara acak bagian amorf menghasilkan oligosakarida dengan panjang yang berbeda dan terbentuk ujung rantai baru. Meryandini et al. (2009) melaporkan menyatakan bahwa enzim eksoglukanase bekerja memotong ujung substrat selulosa kristalin, dimana ujung rantai oligosakarida menjadi selobiosa.

\section{Aktivitas Enzim Xilanase}

Hasil uji jarak berganda Duncan menunjukkan bahwa aktivitas xilanase tertinggi terjadi pada kultur dengan menggunakan substrat berupa pucuk tebu dan eceng gondok.Tongkol jagung memiliki kandungan hemiselulosa paling tinggi, tetapi hasil penelitian menunjukkan bahwa aktivitas enzim xilanasenya lebih rendah dibandingkan dengan kultur dengan menggunakan substrat berupa pucuk tebu dan eceng gondok $(\mathrm{P}<0,05)$. Hal tersebut dapat terjadi karena kandungan lignin pada tongkol jagung lebih tinggi dari pada pucuk tebu dan eceng gondok, sehingga mikroba sulit untuk mendegradasi sehingga produksi enzim xilanase tidak optimal. Hal tersebut sejalan dengan pendapat Judoamidjojo et al. (1989) yang melaporkan bahwahambatan proses hidrolisis serat baik secara asam atau enzimatis adalah adanya lignin yang berfungsi sebagai pelindung sarat. Ryu dan Mendels (1980) dan Biely (1993) melaporkan level produksi xilanase akan menjadi rendah apabila hemiselulosa tidak dapat masuk ke dalam sel mikroba, sehingga substrat tidak dapat menginduksi dan menstimulasi translasi gen penghasil hemiselulase. Hal tersebut menunjukkan bahwa semakin tinggi kadar lignin, maka semakin besar pula hemiselulosa yang akan terikat oleh lignin, sehingga hemiselulosa sulit didegradasi oleh enzim xilanase.

Enzim xilanase termasuk kelompok enzim xilanolitik yang menghidrolisis struktur dasar xilan. Richana et al. (2008) melaporkan xilanase merupakan enzim ekstraseluler yang dapat menghidrolisis xilan menjadi xilooligosakarida dan xilosa.

\section{Aktivitas Spesifik Enzim Endoglukanase, Eksoglukanase dan Xilanase}

Rata-rata nilai aktivitas spesifik enzim endogulanase, eksoglukanase dan xilanase disajikan pada Tabel 3. Analisis ragam menunjukkan substrat yang berbeda berpengaruh nyata terhadap aktivitas spesifik enzim endoglukanase, eksoglukanase dan xilanase $(\mathrm{P}<0,05)$.

Hasil uji jarak berganda Duncan menunjukkan bahwa aktivitas spesifik tertinggi dihasilkan dari substrat kulit kacang. Tingginya aktivitas spesifik enzim endoglukanase, eksoglukanase dan xilanase tidak sejalan dengan aktivitas enzim yang dihasilkan. Hal tersebut disebabkan karena jumlah protein terlarut supernatan kulit kacang lebih rendah dari jumlah protein terlarut supernatan substrat perlakuan lain. Jumlah protein terlarut supernatan dengan substrat sabut kelapa; pucuk tebu; tongkol jagung; kulit kacang; dan eceng gondok berturut - turut adalah 43,436 $\mathrm{mg} / \mathrm{ml} ; 73,436 \mathrm{mg} / \mathrm{ml} ; 51,474 \mathrm{mg} / \mathrm{ml} ; 35,130 \mathrm{mg} / \mathrm{ml}$; dan 47,433 mg/ml. Machfoed et al. (1989) melaporkan bahwajumlah aktivitas spesifik enzim ditentukan dari nilai aktivitas enzim dengan protein terlarut dalamsupernatan enzim. Lehninger (2006) menyatakan bahwa aktivitas enzim dalam mengkatalis substrat dipengaruhi oleh kelengkapan komponen penyusunnya. Daya katalik enzim akan hilang apabila tidak sesuai dengan subunit bagiannya, begitu pula jika komponen asam amino penyusun enzim tidak sesuai atau rusak, aktivitas kataliknya juga akan rusak dan hanya terhitung sebagai protein. Berdasarkan hal tersebut, dapat diketahui bahwa kandungan protein terlarut semakin tinggi, akan semakin menurunkan aktifitas spesifik enzim.

Aktivitas spesifik enzim endoglukanase, eksoglukanase dan xilanase pada inokulum yang diisolasi mengguakan medium selektif cair dan dengan penambahan substrat kulit kacang menunjukkan bahwa enzim yang dihasilkan oleh mikroba tersebut memiliki aktivitas katalik yang paling tinggi dibandingkan dengan inokulum lain $(\mathrm{P}<0,05)$. Agustini et al., (2017) berpendapat bahwa aktivitas spesifk enzim mengindikasikan tingkat kemurnian enzim. Bisswanger (2014) menyatakan bahwa nilai aktivitas spesifik suatu enzim yang semakin besar menunjukkan bahwa

Tabel 3. Rata-rata nilai aktivitas spesifik enzim endogluanase, eksoglukanase dan xilanase

\begin{tabular}{cccc}
\hline \hline \multirow{2}{*}{ Perlakuan } & \multicolumn{3}{c}{ Parameter } \\
\cline { 2 - 4 } & Endoglukanase & Eksoglukanase & Xilanase \\
\hline & $0,014 \pm 0,002^{\mathrm{c}}$ & $0,016 \pm 0,002^{\mathrm{bc}}$ & $0,005 \pm 0,001^{\mathrm{d}}$ \\
$\mathrm{T}_{1}$ & $0,012 \pm 0,002^{\mathrm{c}}$ & $0,013 \pm 0,001^{\mathrm{d}}$ & $0,011 \pm 0,001^{\mathrm{c}}$ \\
$\mathrm{T}_{2}$ & $0,012 \pm 0,002^{\mathrm{c}}$ & $0,014 \pm 0,002^{\mathrm{cd}}$ & $0,014 \pm 0,004^{\mathrm{b}}$ \\
$\mathrm{T}_{3}$ & $0,020 \pm 0,003^{\mathrm{a}}$ & $0,022 \pm 0,001^{\mathrm{a}}$ & $0,018 \pm 0,001^{\mathrm{a}}$ \\
$\mathrm{T}_{4}$ & $0,017 \pm 0,001^{\mathrm{b}}$ & $0,017 \pm 0,001^{\mathrm{b}}$ & $0,018 \pm 0,001^{\mathrm{a}}$ \\
$\mathrm{T}_{5}$ & & &
\end{tabular}

$\overline{\mathrm{a}, \mathrm{b}, \mathrm{c}}$ superskrip yang berbeda pada kolom yang sama menunjukkan perbedaan yang nyata $(\mathrm{P}<0,05) . \mathrm{T}_{1}=$ sabut kelapa; $\mathrm{T}_{2}=$ pucuk tebu; $\mathrm{T}_{3}=$ tongkol jagung; $\mathrm{T}_{4}=$ kulit kacang; $\mathrm{T}_{5}=$ eceng gondok 
semakin murni kadar enzim tersebut pada suatu larutan.

Hasil penelitian menunjukkan bahwa dengan jumlah pemberian yang sama, masing-masing substrat dapat memiliki konsentrasi kristalin, amorf dan xilan yang berbeda. Hal tersebut menunjukkan bahwa kulit kacang memiliki konsentrasi yang lebih tinggi sehingga aktivitas kataliknya lebih tinggi. Hal tersebut sejalan dengan pendapat Herbert et al. (1956) melaporkan bahwa laju pertumbuhan spesifik sebanding dengan konsentrasi substrat, sehingga secara berkelanjutan enzim yang diproduksi perunit substrat tidak konstan. Hal tersebut menunjukkan bahwa semakin tinggi konsentrasi substrat maka kecepatan reaksi katalis semakin tinggi.

Berdasarkan nilai aktivitas spesifik dari ketiga jenis enzim, dapat disimpulkan bahwa proses fermentasi sabut kelapa akan lebih efektif apabila menggunakan inokulum dengan substrat berupa kulit kacang. Pemilihan ini berdasarkan bahwa nilai aktivitas spesifik merupakan gambaran dari kemurnian suatu enzim.

\section{Kualitas Nutrisi Sabut Kelapa Fermentasi}

\section{Kadar protein kasar (PK)}

Pengaruh perlakuan terhadap kadar PK disajikan pada Tabel 4. Analisis ragam menunjukkan bahwa tidak terdapat interaksi antara perlakuan penggunaan persentase inokulum dengan lama peram. Akan tetapi, masing-masing perlakuan penggunaan persentase inokulum dan lama peram berpengaruh nyata terhadap kadar $\mathrm{PK}(\mathrm{P}<0,05)$. Hal ini berati kedua faktor perlakuan tidak atau belum saling mempengaruhi peningkatan kadar PK.
Kadar PK meningkat seiring dengan semakin meningkatnya persentase pemberian inokulum sampai $5 \%$ dan lama waktu peram sampai 14 hari berdasarkan perlakuan yang dicobakan. Hal ini disebabkan karena adanya perbedaan penambahan inokulum yaitu $0,2,5$ dan5\% yang mana inokulum tersebut berisi mikroba sehingga terhitung sebagai protein kasar. Waktu pemeraman sampai 14 hari menyebabkan meningkatnya kesempatan mikroba untuk melakukan pertumbuhan dan fermentasi. Hal tersebut mempengaruhi peningkatan jumlah mikroba dan akan menambah jumlah PK. Adanya penurunan kadar serat kasar dengan semakin lamanya waktu pemeraman sampai 14 hari juga mempengaruhi terjadinya peningkatan kadar protein kasar secara relatif. Hal ini sejalan dengan pendapat Pasaribu (2007) bahwa penanaman mikroba pada substrat membutuhkan lama pemeraman tertentu agar mikroba dapat mengoptimalkan kerja enzim pencerna serat dan meningkatkan kadar protein kasar. Purwadaria et al. (1997) melaporkan bahwa selama proses fermentasi, mikroba berperan sebagai penghasil enzim untuk memecah serat dan meningkatkan kadar protein substrat. Pendapat lain menyatakan bahwa peningkatan jumlah mikroba akan menyebabkan meningkatnya kandungan protein pada produk fermentasi (Wina, 2008).

\section{Kadar Serat Kasar (SK)}

Pengaruh perlakuan terhadap kadar SK disajikan pada Tabel 4. Analisis ragam menunjukkan bahwa terdapat interaksi antara persentase inokulum dan lama peram terhadap kadar SK $(\mathrm{P}<0,05)$. Kadar SK menurun seiring dengan semakin meningkatnya persentase

Tabel 4. Komponen proksimat abut kelapa fermentasi

\begin{tabular}{|c|c|c|c|c|c|}
\hline \multirow{2}{*}{ Perlakuan } & \multicolumn{5}{|c|}{ Parameter } \\
\hline & PK & SK & LK & $\mathrm{ABU}$ & BETN \\
\hline & & & --- $(\%)$----- & 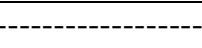 & ------- \\
\hline \multicolumn{6}{|c|}{ Persentase Inokulum x Lama Peram } \\
\hline $\mathrm{P}_{0} \mathrm{H}_{0}$ & $1,89 \pm 0,49^{\mathrm{ns}}$ & $62,46 \pm 2,34^{\mathrm{a}}$ & $7,04 \pm 1,47^{\mathrm{c}}$ & $8,41 \pm 0,59^{\mathrm{e}}$ & $20,21 \pm 3,16^{\mathrm{ns}}$ \\
\hline $\mathrm{P}_{1} \mathrm{H}_{0}$ & $1,95 \pm 0,08^{\mathrm{ns}}$ & $62,40 \pm 2,02^{\mathrm{a}}$ & $7,60 \pm 0,63^{\mathrm{c}}$ & $8,01 \pm 0,69^{\mathrm{e}}$ & $20,04 \pm 2,63^{\mathrm{ns}}$ \\
\hline $\mathrm{P}_{2} \mathrm{H}_{0}$ & $2,17 \pm 0,03^{\mathrm{ns}}$ & $62,36 \pm 2,88^{a}$ & $7,94 \pm 0,39^{c}$ & $8,88 \pm 0,57^{\mathrm{e}}$ & $18,61 \pm 3,53^{\mathrm{ns}}$ \\
\hline $\mathrm{P}_{0} \mathrm{H}_{1}$ & $1,91 \pm 0,06^{\mathrm{ns}}$ & $61,96 \pm 1,64^{\mathrm{a}}$ & $7,90 \pm 0,83^{\mathrm{c}}$ & $7,89 \pm 0,22^{\mathrm{e}}$ & $20,14 \pm 1,55^{\mathrm{ns}}$ \\
\hline $\mathrm{P}_{1} \mathrm{H}_{1}$ & $2,06 \pm 0,16^{\mathrm{ns}}$ & $55,48 \pm 4,36^{\mathrm{b}}$ & $8,77 \pm 4,34^{\mathrm{c}}$ & $13,75 \pm 1,74^{\mathrm{c}}$ & $19,95 \pm 7,23^{\mathrm{ns}}$ \\
\hline $\mathrm{P}_{2} \mathrm{H}_{1}$ & $2,33 \pm 0,09^{\mathrm{ns}}$ & $49,90 \pm 0,85^{\mathrm{c}}$ & $13,53 \pm 4,51^{\mathrm{ab}}$ & $16,41 \pm 1,48^{\mathrm{ab}}$ & $17,83 \pm 7,23^{\mathrm{ns}}$ \\
\hline $\mathrm{P}_{0} \mathrm{H}_{2}$ & $1,94 \pm 0,05^{\mathrm{ns}}$ & $61,34 \pm 2,86^{\mathrm{a}}$ & $7,63 \pm 0,40^{\mathrm{c}}$ & $9,14 \pm 0,46^{\mathrm{d}}$ & $19,95 \pm 3,02^{\mathrm{ns}}$ \\
\hline $\mathrm{P}_{1} \mathrm{H}_{2}$ & $2,09 \pm 0,05^{\mathrm{ns}}$ & $51,70 \pm 2,74^{\mathrm{c}}$ & $10,10 \pm 0,90^{\mathrm{c}}$ & $16,99 \pm 0,54^{\mathrm{a}}$ & $19,12 \pm 3,09^{\mathrm{ns}}$ \\
\hline $\mathrm{P}_{2} \mathrm{H}_{2}$ & $2,49 \pm 0,19^{\mathrm{ns}}$ & $49,91 \pm 1,44^{\mathrm{c}}$ & $16,03 \pm 1,79^{\mathrm{a}}$ & $12,55 \pm 0,74^{\mathrm{cd}}$ & $19,02 \pm 2,56^{\mathrm{ns}}$ \\
\hline \multicolumn{6}{|c|}{ Persentase Inokulum } \\
\hline $\mathrm{P}_{0}$ & $1,92 \pm 0,50^{\mathrm{c}}$ & $61,92 \pm 2,02^{\mathrm{a}}$ & $7,54 \pm 0,98^{b}$ & $8,48 \pm 0,67^{\mathrm{b}}$ & $20,43 \pm 0,98^{\mathrm{ns}}$ \\
\hline $\mathrm{P}_{1}$ & $2,03 \pm 0,12^{\mathrm{b}}$ & $56,53 \pm 5,46^{\mathrm{b}}$ & $8,82 \pm 2,57^{\mathrm{b}}$ & $12,91 \pm 4,01^{\mathrm{a}}$ & $19,12 \pm 2,57^{\mathrm{ns}}$ \\
\hline $\mathrm{P}_{2}$ & $2,33 \pm 0,18^{\mathrm{a}}$ & $54,06 \pm 6,37^{\mathrm{c}}$ & $12,50 \pm 4,35^{\mathrm{a}}$ & $12,80 \pm 3,34^{\mathrm{a}}$ & $18,50 \pm 4,3^{\mathrm{ns}}$ \\
\hline \multicolumn{6}{|l|}{ Lama Peram } \\
\hline $\mathrm{H}_{0}$ & $2,00 \pm 0,14^{\mathrm{b}}$ & $62,41 \pm 2,21^{\mathrm{a}}$ & $7,53 \pm 0,94^{\mathrm{b}}$ & $8,43 \pm 0,67^{\mathrm{b}}$ & $19,63 \pm 0,92^{\mathrm{ns}}$ \\
\hline $\mathrm{H}_{1}$ & $2,10 \pm 0,21^{\mathrm{a}}$ & $55,78 \pm 5,40^{\mathrm{b}}$ & $10,07 \pm 4,91^{\mathrm{a}}$ & $12,88 \pm 3,91^{\mathrm{a}}$ & $19,64 \pm 4,42^{\mathrm{ns}}$ \\
\hline $\mathrm{H}_{2}$ & $2,17 \pm 0,26^{\mathrm{a}}$ & $54,32 \pm 5,83^{b}$ & $11,27 \pm 3,83^{\mathrm{a}}$ & $12,89 \pm 3,40^{\mathrm{a}}$ & $19,36 \pm 2,66^{\mathrm{ns}}$ \\
\hline
\end{tabular}

$\overline{\text { a,b,c }}$ superskrip yang berbeda pada kolom dan baris yang sama menunjukkan perbedaan yang nyata $(\mathrm{P}<0,05) .{ }^{\mathrm{ns}}($ non signifikan $)=$ menunjukkan

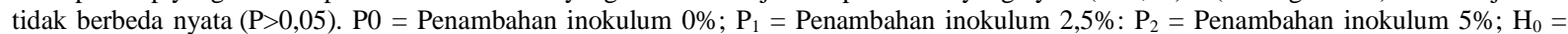
Pemeraman 0 hari; $\mathrm{H}_{1}=$ Pemeraman 7 hari; $\mathrm{H}_{2}=$ Pemeraman 14 hari. 
pemberian inokulum sampai 5\% dan lama waktu peram sampai 14 hari berdasarkan perlakuan yang dicobakan. Hal tersebut desebabkan karena dengan peningkatan jumlah starter sampai 5\% dan peningkatan lama waktu pemeraman samapi 14 hari, secara bersama-sama menyebabkan kemampuan mendegradasi serat menjadi lebih tinggi dan meningkatkan kesempatan mikroba pencerna serat untuk melakukan pertumbuhan dan fermentasi. Hal ini sejalan dengan pendapat Musnandar (2006), bahwa lama waktu fermentasi dan jumlah inokulum yang cukup akan meningkatkan kecepatan mikroba untuk mendegradasi serat. Pendapat lain menyatakan bahwa bakteri selulolitik menghasilkan enzim selulase yang mampu memecah selulosamenjadi glukosa, selanjutnya glukosa yang akan digunakan sebagai sumber karbon dan energi untuk kebutuhan hidupnya (Gamayanti et al., 2012). Hal tersebut menunjukkan bahwa inokulum hasil isolasi mampu mendegradasi serat sabut kelapa pada jumlah penggunaan inokulum sampai $5 \%$ dan lama peram sampai 14 hari, sehingga mampu menurunkan kadar SK.

\section{Kadar Lemak Kasar (LK)}

Pengaruh perlakuan terhadap kadar LK disajikan pada Tabel 4. Analisis ragam menunjukkan bahwa terdapat pengaruh interaksi antara perlakuan penggunaan persentase inokulum dengan lama peram terhadap kadar LK $(\mathrm{P}<0,05)$. Hal ini berarti kedua faktor perlakuan sama-sama saling mempengaruhi kadar LK. Kadar LK meningkat seiring dengan meningkatnya persentase pemberian inokulum sampai 5\% dan lama waktu pemeraman sampai 14 hari. Peningkatan kadar LK diiringi dengan penurunan kadar SK pada perlakuan tersebut. Hal tersebut disebabkan karena komponen proksimat yang lain berubah, sehingga persentase LK menjadi naik. Selain itu, starter yang digunakan untuk fermentasi sabut kelapa adalah starter yang hanya mengandung mikroba pencerna serat, sehingga enzim yang produksi hanya dapat mendegradasi substrat berupa serat dan tidak dapat mendegradasi substrat lain. Hal ini sejalan dengan pendapat Lehninger (2006) yang menjelaskan bahwa mikroba hanya dapat mensintesis enzim dengan kerja spesifik pada substrat tertentu. Elyza et al. (2015) melaporkan bahwa enzim lipase dihasilkan oleh mikroba lipolitik untuk mendegradasi lemak.

\section{Kadar Abu}

Pengaruh perlakuan terhadap kadar abu disajikan pada Tabel 4. Analisis ragam menunjukkan bahwa terdapat interaksi antara perlakuan penggunaan persentase inokulum dengan lama peram terhadap kadar abu $(\mathrm{P}<0,05)$. Hal ini berarti kedua faktor perlakuan sama-sama saling mempengaruhi kadar abu.

Kadar abu merupakan gambaran dari kandungan bahan organik. Kadar abu yang semakin rendah merepresentasikan kandungan bahan organik yang semakin tinggi. Meningkatnya kadar abu pada perakuan $\mathrm{P}_{1}$ dan $\mathrm{P}_{2}$ yang diberi perlakuan $\mathrm{H}_{1}$ dan $\mathrm{H}_{2}$ menunjukkan bahwa bahan organik pada sabut kelapa telah dicerna oleh mikroba selama proses fermentasi, sehingga kandungan bahan organiknya semakin menurun. Hal ini sejalan dengan pendapat Purwadaria et al. (1997) bahwa peningkatan kadar abu menunjukkan berkurangnya bahan organik substrat. Irawan et al. (2012) melaporkan bahwa pada proses fermentasi, mikroba mencerna bahan organik menjadi gula sederhana.

\section{Kadar Bahan Ekstrak Tanpa Nitrogen (BETN)}

Rata-rata kadar BETN sabut kelapa fermentasi disajikan pada Tabel 4. Analisis ragam menunjukkan bahwa tidak terdapat interaksi antara penggunaan persentase inokulum dengan lama peram terhadap kadar BETN. Hal ini berarti kedua faktor perlakuan secara bersama-sama tidak saling mempengaruhi kadar BETN. Masing-masing perlakuan penggunaan persentase inokulum dan lama peram juga tidak berpengaruh nyata terhadap kadar BETN.

Berdasarkan hasil analisis ragam, semua perlakuan menghasilkan nilai yang sama sehingga tidak terjadi perubahan kandungan BETN pada sabut kelapa fermentasi. Hal tersebut disebabkan oleh adanya penambahan molases pada campuran sabut kelapa yang akan difermentasi, sehingga mikroba menggunakan gula sederhana dari molases untuk digunakan sebagai energi pada proses. Hal tersebut berpengaruh terhadap aktivitas mikroba untuk tidak banyak menggunakan BETN yang terkandung pada sabut kelapa sebagai sumber energi utama. Kusmiati et al. (2007) dan Yunartono et al. (2017) melaporkan bahwa molases berfungsi sebagai sumber karbon dan penghasil energi utama untuk mikroba pada proses fermentasi.

\section{KESIMPULAN}

Penggunaan substrat kulit kacang menghasilkan kultur mikroba pencerna serat terbaik. Kualitas sabut kelapa dapat meningkat seiring dengan peningkatan penggunaan inokulum dan lama pemeraman. Kualitas fermentasi sabut kelapa terbaik terjadi pada penggunaan inokulum sebanyak $5 \%$ dan pemeraman selama 14 hari ditinjau dari kadar protein kasar dan serat kasar.

\section{DAFTAR PUSTAKA}

Adeyi, O. 2010. Proximate composition of some agricultural wastes in Nigeria and their potential use in activated carbon production. Journal Applied Sciences Environmental Management 14(1): 55-58.

Agustini, L., R.S.B. Irianto, M. Turjaman, S.A. Faulina, R. Ariantari, S. Stephandra, H. Yuniar, Aryanto, Najmulah dan A. Yani. 2013. Pengaruh kondisi kultur pada aktivitas selulase isolat Pycnoporus sp. dan Phlebiopsis sp. Jurnal Selulosa 7(2): 7990. 
AOAC. 2005. Official methods of analysis of the association of analytical chemist. 18th Ed. Assoc of Offi. Anal. Chem. Arlington.

Bachrudin, Z., A.S.M. Sofro and B.I.M. Tampoebolon. 1998. The characterization of cellulase produced by buffalo rumen microbe: determination of michaleis constantas ( $\mathrm{Km}$ and maximum velocity $(\mathrm{Vm})$ ). Indonesian Journal of Biotechnology 6: 185-188.

Badan Pusat Statistik. 2018. Statistik Perkebunan Indonesia. Badan Pusat Statistik. Jakarta.

Biely, P. 1993. Biochemical aspects of the production of microbialhemicellulase. In: Hemicellulose and Hemicellulases (Ed. Coughlan, M.P. and G.P. Hazlewood). Portland Press. London. pp. 29-51.

Bisswanger, H. 2014. Enzyme assays. Perspectives in Science 1: 41-55.

Elyza, F., N. Gofar dan Munawar. 2015. Identifikasi dan uji potensi bakteri lipolitik limbah SBE (spent bleaching earth). Jurnal Ilmu Lingkungan 13(1): 12-18.

Gamayanti, K.Y., A. Pertiwiningrum dan L.M. Yusiati. Pengruh penggunaan limbah cairan rumen dan lumpur gambut sebagai starter dalam proses fermentasi metanogenik. 2012. Buletin Perternakan 36: 32-39.

Guman, I.B.W., K. Buda dan I.M.Y.S. Guna. 2010. Pengaruh perlakuan delignifikasi dengan larutan $\mathrm{NaOH}$ dan konsentrasi substrat jerami padi terhadap produksi enzim selulase dari Aspergillus niger NRRL A-II, 264. Jurnal Biologi 14: 55-61.

Haryanto, T. dan D. Suheryanto. 2014. Pemisahan sabut kelapa menjadi serat kelapa dengan alat pengolahan (defibring mechine) untuk usaha kecil. Dalam: Prossiding Seminar Nasional Rekayasa Kimia dan Proses. Semarang, Indonesia. pp. 1-9.

Herbert, D., R. Elsworth and R.C. Telling. 1956. The continuous culture of bacteria: A theoretical and experimental study. Journal of General Microbiology 14(3): 601-622.

Irawan, P., I. Sutrisno dan C.S. Utama. 2012. Komponen proksimat pada kombinasi jerami padi dan jerami jagung yang difermentasi dengan berbagai aras isi rumen kerbau. Animal Agriculture Journal 1(2): 17-30.

Judoamidjojo, R.M., E.G Said dan L. Hartoto. 1989. Biokonversi. PAU Bioteknologi IPB. Bogor.

Khoshnevisan, K., A.K. Bordbar, D. Zare, D. Davoodi, M. Noruzi, M. Barkhi and M. Tabatabaei. 2011. Immobilization of cellulase enzyme on superparamagnetic nanoparticles and determination of its acticity and stability. Chemical Engineering Journal 171(2): 669-673.

Kusmiati, S.R. Tamat, E. Jusuf danR. Istiningsih. 2007. Produksi glukan dari dua galur Agrobacterium sp. pada media mengandung kombinasi molase dan urasil. Biodiversitas 8(1): 123-129.
Lee, S.H., T.V. Doherty, R.J. Linhardt and J.S. Dordick. 2009. Ionic liquid-mediated selective extraction of lignin from wood leading to enhanced enzymatic cellulose hydrolysis. Biotechnology and Bioengineering 102(5) :13681376.

Lehninger, D.N. 2006. Principles of biochemistry. 4th Edittion. University of Wisconsin. Medison.

Lorica, R.G. and F.R. Uyenco. 1982. Agricultural and food processing wastes as potential substrates. In: Microbial Protein Production: Chemical Analysis. Science Diliman Publisher. Quezon.

Machfoed, E.G., Said dan Krisnani. 1989. Fermentor. Petunjuk Laboratorium. PAU Pangan dan Gizi. IPB. Bogor.

Meryandini, A., W. Widosari, B. Maranatha, T.C. Sunarti, N. Rachmania dan H. Satria. 2009. Isolasi bakteri selulolitik dan karakterisasi enzimnya. Makara Sains 13(1): 33-38.

Miller, G.L. 1959. Use of dinitrosalicylic acid reagent for determination ofreducing sugar. Analytical Chemistry 31(3):426-428.

Musnandar, E. 2006. Pengaruh dosis inokulum Marasmius sp. dan inkubasi terhadap kandungan komponen serat dan protein murni pada sabut kelapa sawit untuk bahan pakan ternak. Jurnal Ilmu-Ilmu Peternakan. 9(4): 225-234.

Neto, C.P.C.T., F.F.H. Ferreira, F.C. Bezerra, R.F. Sousa and M.L.F. Cavalcanti. 2004. Efeito de diferentes substratos na aclimatizacao "ex-vitro" de mudas de Violeta Africana (Saintpaulia ionantha Wendl.). Revista de Biologia e Ciencias da Terra 4(2): 2-6.

Pasaribu, T. 2007. Produk fermentasi limbah pertanian sebagai bahan pakan unggas di Indonesia. Wartazoa 17: 109-116.

Plummer, D.T. 1971. An introduction to biochemistry analysis. Mc.Graw Hill Publ. Co. Ltd. Bombay.

Pradhan, K. 1994. Rumen ecosystem in relation to cattle and buffalo nutrition. In: Wanapat, M. and K. Sommart (Eds.), Proc. The 1st Asian Buffalo Association Congress. Khon Kaen University, Khon Kaen. pp. 221-242.

Purwadaria T., T. Haryati, A.P. Sinurat, I.P. Kompiang, Supriyati dan J. Darma. 1997. The correlation between amylase and selulase activity with starch and fiber content on the fermentation of "cassapro" (cassava protein) with Aspergillus niger. In: Proceeding of the Indonesian Biotechnology Consortium IUC Biotechnology. Bogor, Indonesia.pp. 379-390.

Rahmadani, S. 2011. Pengaruh penambahan serat sabut kelapa terhadap parameter kuat geser tanah berpasir. Jurnal SMARTek 9(3): 187-195.

Ryu, D.D. and M. Mendels. 1980. Cellulases: biosynthesis and aplication. Enzyme and Microbial Technology 2(2): 91-101.

Singhania, R.R., A.K. Patel, R.K. Sukumaran, C. 
Larrochea and A. Pandey. 2013. Role and significance of beta-glucosidases in the hydrolysis of cellulose for bioethanol production. Bioresource Technology 127 500-507.

Sitindaon, S.H. 2013. Inventarisasi potensi bahan pakan ternak ruminansia di Provinsi Riau. Jurnal Peternakan 1(10): 18-23.

Wanapat, M., R. Pilajun and P. Kongmun. 2009a. Ruminal ecology of swamp buffalo as influenced by dietary sources. Journal Animal Feed Science and Technology 151: 205-214.

Wanapat, M., K. Sommart, C. Wachirapakorn, S. Uriyapongson and C. Wattanachant. 1994. Recent advances in swamp buffal nutrition and feeding. In: Wanapat, M., Sommart, K. (Eds.), Proc. the 1st Asian Buffalo Association Congress. Khon Kaen University, Khon Kaen. pp. 221-242. Wanapat, M., S. Polyorach, K. Boonnop, C. Mapato and A. Cherdthong. 2009b. Effects of treating rice straw with urea or urea and calcium hydroxide upon intake, digestibility, rumen fermentation and milk yield of dairy cows. Livestock Science 125: 238-243.

Wina, E. 2008. Teknologi Pemanfaatan dalam Pakan untuk Meningkatkan Produktivitas Tenak Ruminansia di Indonesia. Balai Penelitian Ternak. Bogor.

Yunianti, A.D., S. Suhasman and S. Sahriyanti. 2015. Basic properties and nanostructure of wood from four fast growing species from a community forest. Journal of Indian Academy of Wood Science 12(2): 94-98.

Yanuartono, A. Nururrozi, S. Indarjulianto, $H$. Purnamaningsih dan S. Rahardjo. 2017. Molasses: dampak negatif pada ruminansia. Jurnal IlmuIlmu Peternakan 27 (2): 25-34. 